\title{
Szív és érrendszeri betegségek kérdéséhez az ókori egyiptomi forrásokban
}

\section{On the question of the diseases of cardio-vascular diseases in the ancient Egyptian sources}

Győry Hedvig PhD egyiptológus

Szépmüvészeti Múzeum

email: hedvig.gyory@gmail.com

Initially submitted March 30, 2020; accepted for publication Apr.28, 2020

Ancient Egyptian medicine is an evidence based science built up on many meticulous observations and practical procedures, which are, however, accompanied also by magical explanations. One of their big medical achievement is the development of their metu(mtw)-system with the heart in its centre. They had two different names for the heart: ib (jb) and hati (HAtj). In everyday life, their use seems to overlap each other, but in the New Kingdom medical texts both have their special context. This study goes through the prescriptions where their conditions are medicated, and analyses the specific treatments. They give physical explanations to the functions of the metu-system, which transfers the „speech of the hati-heart”, i.e. the pulse. The first one does it from anatomical-physiological point of view, while the second from pathological one, explaining how its ill-function leads through the paralysis of the leg to death, practically describing the peripheral atherosclerosis. This was as frequent at that time, as today - based on the researches made on ancient Egyptian mummies. The same discovery was made only millennia later, by Jean Cruveilhier, when he studied the phlebitis.

Kulcsszó: orvoslás, ókori Egyiptom, szív, erek, vérkeringés, érelmeszesedés, múmia

Keywords: medicine, ancient Egypt, heart, arteries, blood circulation, atherosclerosis, mummies

Az ókori egyiptomiak orvosi ismereteiről számos papirusz tanúskodik. ${ }^{1}$ Jelentős részük recept gyüjtemény vagy a gyógyítást szolgáló ráolvasás, attól függően, hogy melyik gyógyító csoport használta őket. Ezek az orvosi és iatromágikus papiruszok jól mutatják, mennyire szakosodott volt annak idején a gyógyító tevékenység. Voltak azonban valamennyi területre vonatkozó, közös elemek, mint például a diagnózis felállításában a pulzus mérése. ${ }^{2}$ Ezt minden orvoslással foglalkozó szakember a szív beszédeként fogta fel, és a test különböző pontjain tudta mérni, mivel úgy tapasztalták, hogy a szív egy speciális hálózatot müködtetve a szervezet egészében tud ,beszélni”. A 18. és 19. dinasztia korából külön orvosi könyvek maradtak fenn az Ebers és a Berlini orvosi papirusz receptgyüjteményei között, melyek ezt a hálózatos

\footnotetext{
${ }^{1}$ Sok átfogó és elemző munka született a témában, a szerző összefoglalóját a fontosabb munkák felsorolásával ld. Győry 2008. 2 A mérés módjáról nem írnak a szövegek, de elképzelhető, hogy használhattak időmérő eszközt: Breasted 1930,106 említ III. Thutmoszisz és Merneptah fáraó idejéből ilyen eszközt. Később, a Kr.e. 3. sz-ban tudjuk, hogy az alexandriai Hérophilosnak volt kifejezett pulzus-mérője. A pulzus mennyiségének a megállapításáról tanúskodik maga az orvosi vizsgálat megnevezésére szolgáló, már a legkorábbi orvosi papiruszokban is használt szó, a xaj. Ennek alapjelentése a „kimér (alapértelemben gabonát)”, tehát szintén számmal kifejezhető mennyiségre utal. Ezt megerősíti, hogy az jp „,számol” szót is használták ilyen alkalommal. http://www.kaleidoscopehistory.hu Győry Hedvig PhD
} 
rendszert ismertetik (Eb854-856, Brl163). ${ }^{3}$ További könyvek a szív speciális elváltozásainak a kezelését adják meg, de más témájú könyvekben is elö-elö kerül néhány szívvel kapcsolatos eset.

A cikkben ezeket a mai tudományban a kardiológia, angiológia és érsebészet területére eső, korabeli ismereteket tekintem át. Ahogy a mai világban az angiológia az artériák, a vénák és a nyirokerek élettani és patológiás müködésével foglalkozik, a fáraó kori orvosok sem csupán a véredényeket értették a szervezetet behálózó rendszer alatt. Ők ezt a mainál is bővebben, a szervezetben található valamennyi hasonló megjelenésű elemekkel együttesen kezelték, és egy közös szóval a metu-val (mtw) nevezték meg. Ennek a fordítása így a szövegkörnyezetnek megfelelő értelmezés alapján éppúgy lehet artéria és véna, mint nyirokér, ín, ideg vagy például akár izom, könnycsatorna is, ill. minden más, csatornára emlékeztető, csőszerü képződmény az emberi szervezetben. Elképzelhető, hogy maga a szó az óbirodalmi emlékekről ismert $\mathrm{mtj}$,,kötél, madzag” jelentésre vezethető vissza, ${ }^{4}$ hiszen ez $m t$ formában is jelentheti ugyanezt. ${ }^{5}$

Bár a korabeli viszonyok között rendkívül specializálódott az egyiptomi orvostudomány, a metuval nem foglalkozott önálló szakág, ennek ismerete valamennyi gyógyítással foglalkozó szakember számára alapvető volt. A betegségek megállapításánál a metu „,beszédét” (mdw), vagyis ebben az esetben a pulzust mérve állapították meg a betegség mértékét, tehát a vérkeringés állapotát. ${ }^{6}$ A szunu (swnw), vagyis (világi) orvos egyike volt ezeknek. Ök használták az Ebers papiruszt ${ }^{7}$ és Berlini papiruszt, ${ }^{8}$ melyekben a keringési rendszert külön könyvekben tárgyalták. Ök nem operáltak, gyógyszerekkel kezelték a betegeket.

\section{A szív fogalma}

Valójában több szó fordul elő az ókori egyiptomi forrásokban szív jelentéssel: HAtj, jb és jdr. ${ }^{9}$ Ez utóbbit azonban csak a halotti rítusokkal foglalkozó, Augusztus császár 22. uralkodási évében lejegyzett hieratikus-démotikus Rhind 1. papiruszból ismerjük testrész jelentéssel, ahol a szív és hús determinatívum szerepel a szó végén. ${ }^{10}$ Minthogy a klasszikus egyiptomi szövegekből más jelentéseit ismerjük, ezt csak a

\footnotetext{
3 Magyar fordítása és magyarázatát ld. Győry 2002.

${ }^{4} \underline{\mathrm{http}}$ ://aaew.bbaw.de/tla/servlet/GetTextDetails? $\mathrm{u}=$ guest $\& \mathrm{f}=0 \& \mathrm{l}=0 \& \mathrm{db}=0 \& \mathrm{tc}=17584$ : pCairo 58063 frame 9 (30 N) - abusziri papirusztöredéken, és http://aaew.bbaw.de/tla/servlet/GetTextDetails?u=guest\&f=0\&l=0\&db=0\&tc=22590: a Pyr 663a / PT378, ahol a kígyók az isten kötelét alkotják

5 pl. PT 1006 http://aaew.bbaw.de/tla/servlet/GetWcnDetails? $\mathrm{u}=$ guest $\& \mathrm{f}=0 \& \mathrm{l}=0 \& w n=77310 \& \mathrm{db}=0$

${ }^{6}$ Breasted 1930, 106 a mérésre szolgáló eszközröl írja, hogy III. Thutmoszisz 1. palesztin hadjáratára vittek erre a célra használható hordozható eszközt, és az ásatások során találtak Gezerben egy hordozható napórát Merneptah fáraó nevével ellátva. A hellénisztikus korban az alexandriai orvosi iskola egyik alapítója, Hérophilosz esetében pedig jól ismert, hogy a pulzust mérőeszközzel mérte. A pulzusmérés fontosságát maga az orvosi vizsgálatot megnevező khai (xaj) szó is jól mutatja, hiszen alapjelentése a „mérés”, amit a gabona mennyiségének a megállapítására ugyanúgy használtak. Sőt a szív hangjának a megállapítására használták az jp ,számol” szót is. Tehát a pulzusmérése mindenféle diagnózis felállításának alapvető eleme volt.

7 Ebers 1875, Wreszinsky 1913, Ghalioungui 1987.

8 Wreszinsky 1909.

9 További szívvel determinált óegyiptomi szó a bsk ,zsigerek, szív”. A Piramisszövegekben és a Halottak Könyve papiruszain fordul elő, amikor is elfogyasztásával fenyegetnek - az elpusztít körülírásaként, és ugyan a szó szív determinatívummal szerepel, de a szövegkörnyezet alapján bármely belső szervre, különösen a zsigerekre vonatkozhat, így jelen témánk szempontjából nem releváns.

Az istenek és a király szívét néha a nTr.t „,isteni” szó szív determinatívumos írásával is rögzítették a Ptolemaiosz- és római korban, aminek szintén egyértelműen csak vallási jelentősége volt. Helck 1955; Hintze 1955 ; Müller 1966.

10 Tekintve, hogy az jdr szó alapjelentése az „összekötni” igéhez kapcsolódik, már a Piramisszövegekben (295, § 40+13) „övcsomóként” használják, és később a „kötés”, és „sebészi varrás, öltés”, ill. az „összekötöz” jelentésekkel ismert. A HAtj szív speciális orvosi értelmével teljesen összhangban van egy hálózatot összefogó szervként. Thesaurus
}

http://www.kaleidoscopehistory.hu

Győry Hedvig PhD 
nyelvfejlödés egy késői fázisaként tudjuk értelmezni. Jelentését tovább árnyalja, hogy a démotikus nyelvü fordításban a HAtj-szívet nevezik meg a helyén, tehát ekkoriban azzal tekintették egyenértékünek. Tekintve, hogy sehol máshol, és így az egyiptomi orvosi szövegekben sem tudunk ilyen jelentéséről, a továbbiakban ezzel a szív megnevezéssel nem foglalkozunk. ${ }^{11}$

A két másik szó jelentése is a fáraók 3000 éve alatt jelentős változáson mehetett keresztül, amit jól tükröz, hogy a későkori szövegekben a klasszikus jb-szívet jellemzően a HAtj-szív szóval fordították maguk az egyiptomiak is. ${ }^{12}$ Nyelvtörténeti szempontból az jb-szó ősibb, hiszen még az afro-ázsiai nyelvcsalád közös szókincséből származik, míg a HAtj szó már egyértelműen az önállóvá vált ókori egyiptomi nyelv korszakában képződött: ,ami elöl van”. ${ }^{13}$ Létrejötte bizonyára valamilyen szükség kielégítésére szolgált, és valószínütlen, hogy egy vele teljesen azonos jelentésü szó szinonimájaként alkották volna meg. A nyelv fejlődése során azonban úgy tünik, hogy az azonosulás bekövetkezett, ${ }^{14}$ mégpedig a szövegek alapján feltételezhetően az Újbirodalom folyamán, hiszen a 21. dinasztia idejéből fennmaradt „orákulum amulettek” szövegeiben kivétel nélkül a HAtj szót használták a szív megnevezésére, és amikor az jb szó előfordul, az a „kívánság” értelemben szerepel (L6, rs42) ${ }^{15}$. A folyamat nyilván nem egyik pillanatról a másikra ment végbe, és mivel az újbirodalmi orvosi szövegekben még mindkettő bőségesen megtalálható, feltételezhetően éppen ebben az időszakban történt meg az átalakulás. Az írott nyelv a beszélt nyelvhez képest mindig később rögzíti a változásokat. Minthogy pedig az egyiptomi tudomány jellemzően a régiség, ősiség követését rendkívül fontosnak tartotta, az orvosi szövegek ennél korábbi nyelvi állapotot öriztek meg. Ezt a különböző szövegmagyarázatok, megjegyzések is jól tükrözik, hiszen azért volt rájuk szükség, hogy a kortárs orvosok megértsék a korábbi nyelvi fázisban megfogalmazott eredeti szövegeket.

\section{Orvoslás}

A szívre vonatkozó gyógyító szövegek gyakorlatilag receptek vagy magyarázatok, és különböző betegségeket neveznek meg. Ezeket a betegségeket főként növényi, ásványi, állati, kisebb mértékben emberi eredetű, vagy emberi tevékenységgel előállított anyagokkal kezelték. A kellö hatás elérése érdekében az istenek segítségét kérték. Az orvoslás folyamatát úgy képzelhetjük el, mint a müszeres, vizsgálati úton folytatott kutatáson alapuló orvostudomány kialakulása elött gyakorolt, a középkori vagy akár újkori gyógykezeléseket. Voltak szunu-orvosok, az akkori orvos-doktorok: az ő receptjeiket tartalmazzák a ma „orvosi” könyveknek nevezett papiruszok. A következő kategória az egyiptomi felfogás szerint az uabpapok (wab), - elsősorban Szahmet istennő szolgálatában álltak ezek a gyógyító „tiszta”-papok, akik az említett időszakban orvosi szempontból leginkább a kirurgusnak felelnek meg. Ök operáltak, viszont nem borbélykodtak, ezzel szemben Szahmet istennőnek a szertartásait látták el és imádkoztak. Tevékenységük a járványok megelőzésében töltött még be fontos szerepet. Harmadik kategóriaként az egyiptomiak a varázslókat, ún. sza (sA: „amulett, védelem”)-embereket nevezik meg, akik fő müködési területét ma

LinguaeAegyptiae:http://aaew.bbaw.de/tla/servlet/DzaBrowser?START.x=28\&START.y=142\&newpid=DZA+21.490.930\&dis pscale $=100 \&$ set $=E M \& w n=34190 \&$ lastpid $=21490930 \& w i d=0$

${ }_{11}$ Westendorf 1999, 109: a jdr helyett jb-et olvas itt is.

12 pl. Schott 1954, 206.

${ }^{13}$ Ritner a két szó egymáshoz való viszonyát az eltérő szemlélettel hozza összefüggésbe: az jb a szív központi elhelyezkedését tükrözi, a HAtj az elvont „elöl van”, tehát elsődleges szerv mögöttes értelmezését említi (Ritner 2006, 100, 11. jegyzet).

${ }^{14}$ Az azonos jelentést támogatja Westendorf 1999, 108-109, aki szerint a HAtj még a rA-jb ,jb-szív szája" tevékenységét is átvette.

15 Edwards 1960. Az jb-szivet elvont formában, emberekre vonatkoztatva később is szívesen használták, pl. „Add, hogy a szivek (= emberek) kegyesek legyenek hozzá" $(\mathrm{Dj}=\mathrm{k} \mathrm{jmA} \mathrm{n}=\mathrm{f} \mathrm{jb} . \mathrm{w})$, in Klotz 2015, 67 - Ptolemaiosz kor. http://www.kaleidoscopehistory.hu

Győry Hedvig PhD 
iatromágiának (gyógyító mágia) nevezzük. Közéjük tartoztak például Szelket istennő papjai, akik a kígyómarás, skorpiócsípés és más állati bántalomra specializálódtak, és további ráolvasó emberek, akik a legkülönbözőbb bajokra ismertek varázsigéket, vagy varázserejü tárgyakat és rítusokat.

Írott forrásaink csoportosítása tehát a fö tevékenységeknek megfelelően a tapasztalati eredmények ill. megfigyelések alapján létrejött receptekre, leírásokra és elörejelzésekre, a ma használatos szakkifejezéssel orvosi szövegekre, és az isteneket befolyásolni igyekvő ráolvasásokra vagy varázsigékre, a iatromágikus szövegekre oszthatók. Sebészi beavatkozásról nagyon keveset tudunk, szinte csak a Smith papiruszban van róla szó, ${ }^{16}$ de a szívet és annak hálózati rendszerét a pulzus mérésén kívül más kezelési módnál nem említi. A szív korabeli állapotát, akkor számon tartott bajait az orvosi szövegek alapján ismerjük.

A korabeli orvosi szakkönyvek mindkét szív formája más jellegü szövegekben is gyakori, hiszen a szívet a szervezet fizikai értelemben vett testrészén kívül a gondolkodás és érzelmek középpontjának is tekintették. ${ }^{17}$ E mellett használták számos kanonizálódott szófordulat, kifejezés részeként egyik vagy másik formáját, ${ }^{18}$ amik néha egyenértékü szóként, szinonimaként szerepeltek. ${ }^{19}$

Az orvosi szövegekben viszont, legalábbis bizonyos esetekben, mint az un. anatómiai traktátusokban, a két szó jelentése elkülöníthető. Úgy látom, az jb szív a konkrét szervet jelöli, a HAty-szív viszont az egész szervezetet átfogó hálózatot, és annak középpontját, hiszen a korabeli keringési rendszert képező metu-hálózat egyes elemeiben a HAty-szív „,beszélt”. ${ }^{20}$ Nem meglepő ezek után, hogy amikor az újbirodalmi orvosok könyvekbe rendezve másolták le az orvosi recepteket, akkor éppúgy megnevezték az jb-szív, mint ahogy a HAty-szív könyvét, jelezve, hogy egy szervről, vagy az egész testet behálózó rendszerről van-e szó. Mindkét kifejezés azonban előfordul más betegségeket tartalmazó könyvekben is.

jb sziv

Az Ebers papiruszon az jb-szívre vonatkozó könyv a Xt (test, törzs, has) gyüjteményes könyvében található, és címe egy számunkra nehezen megfogható betegséget jelöl: ,Az orvosságok kezdete, amely az jb-szívet a kenyér befogadására készteti" (Eb 284-293 + H50), vagyis egy olyan kór, melynek a vezető tünete számukra az volt, hogy a páciens nem akarta / tudta megenni a kenyeret. Mivel a kenyér képletesen a táplálékot jelentette, ezt a tünetet az evés akadályoztatásával lehet leginkább ma megnevezni, ami egyfajta táplálkozási zavar. Ezt sokféle betegség okozhatja, ami mai ismereteink szerint a gyomorráktól akár a súlyos szívelégtelenségig terjedhet. Lehet pszichoszomatikus és szomatikus megbetegedés. Ma önálló betegségnek is tekinthetjük (anorexia nervosa - nem evés, vagy ennek ellentéte, a bulimia - túlevés), és elsősorban

16 Összefoglalóan ld. Győry 2008.

17 pl. Breasted 1901, 464-465, Piankoff 1930; Brunner 1965; Müller 1966, Brunner 1977; Assmann 1993, Assmann 1994.

18 Néhány példa: jbjb- „szív szive”, vagyis ,kedvenc”, amit úgy is kifejezhettek, hogy jm.j-jb-n-nb=f ,aki ura szivében van"; wbA (jb) - nyíltszívü, okos,; wmt (jb) - határozott; $w D A(j b)$ - ,ép szívü” vidám; pgA (jb) - „szívét kitáró” nyíltszívü; $p X r(j b / H A t j)-$, a szivet körüljáró”, részvétet érzö; $\underline{m i}(j b)$ - „elárasztott szívü”, feledékeny mtj (jb / HAtj) / mtr (jb / HAtj) - ,igazságos, helyes szívü” őszinte; Hwa-jb / Hns-jb-szük szívü = korlátolt; $\underline{S n i}$

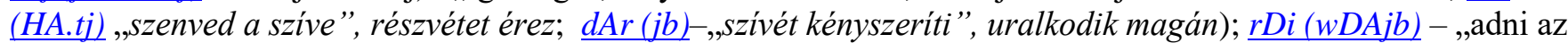
ép szívet”, közöl; rDi (HA.tj) - ,szivét adja” gondoskodik.

19 pl. jaj $(j b)=$ jaj (HAtj) - örül, elégedett ,megmossa a szivet"

20 A metu rendszer a korabeli elképzelések szerint központi szerepet játszott mind a betegséget okozó patogén anyagok, mind az orvosságok szállításában - Ssp „,befogadta” azokat, pl. Eb642 és Eb856d. A betegség lehetett a metu ellensége, pl. Eb876. http://www.kaleidoscopehistory.hu

Győry Hedvig PhD 
pszichoterápiás módszerekkel (kognitív terápia, családterápia ...) igyekszünk megoldani, és nem hozzuk kapcsolatba a szívvel, noha a következménye az általános legyengülés következtében a „szív beszédén”, vagyis a csökkent pulzuson lemérhetö. A nem-evés azonban nem feltétlenül csak az étvágy elvesztése miatt történhet. Lehet annyira legyengült egy beteg, hogy azért nem akar vagy tud enni, ill. egyes betegségeknek is lehet kísérő jelensége. Ilyenre utal, hogy az Eb188-ban ${ }^{21}$ és az Eb205-ben ${ }^{22}$ a rA-jb szenvedésekor ezt a tünetet is feljegyezték. Az Eb206-ban pedig egy komplett tünetegyüttes részeként a szöveg a nem-akarás okát is megadja: ,jb-szíve csapkod, és a fájdalom belép neki, ha bármilyen kenyeret evett, és szük az átjárás a rA-jb-jén, és mind a két lábszára és a dbbw-testrésze szenved, de két combja nem" (jw jb=f aaw=f, qsn aq $\mathrm{n}=\mathrm{f}$, wnm.n=f $\mathrm{t}$ nb, jw Hns swA Hr rA-jb=f, jw mn=f wartj=fy, dbbw nn mntj=fy).

Az utóbbi példák mind az jb-szív „kapujának, elöcsarnokának, szájának” (rA-jb) a könyvéből (Eb 188-216) származnak. ${ }^{23}$ Ezt sokáig gyomornak fordították, Walker kutatásai alapján azonban helytelenül. ${ }^{24}$ Annál is inkább, mivel az egyik jellegzetes tünetegyüttes, amit a rA-jb-hez kapcsoltak, az wAD, amit ,zöldnek, frissnek" lehet fordítani.

Eb $191(37,10-17)=\operatorname{Eb} 194(38,10-17)$

Ha megvizsgálsz egy embert, aki a rA-jb-jétöl szenved, és a karján és a mellkasán, a rA-jb oldalán szenved, azt mondják erre, ez az wAD betegség,

Akkor ezt mondd: A szájon bejövő dolog ez. A halott az, amely közeledik felé.

Akkor készíts neki vegyes-gyógyfüves szereket: tHwj termés 1, földitök 1, menta? 1, Conyza? 1, hatos-árpa dSrw-ja 1, olajban megfözni, és az ember által meginni.

Akkor tedd kezed rá, behajlitván, amíg karjának kellemes, és mentes az jh/Ah-fájdalomtól.

Akkor ezt mondd: Elment ez az, Ah/jh-fájdalom a vastagbélbe, a feneke felé.

A szert ne ismételd meg!

(jr $x A j=k$ s Hr mn $r A-j b=f$, jw=f mn=f $g A b=f$ mnd $=f$ gs $n$ rA-jb=f,

jw Dd.tw r=f: wAD pw,

Dd. $x r=k r=s$ : Aqt $m$ rA pw, $m[w] t$ pw, xns.n=f.

jrj.xr=k n=f spw Ddb n smyt: prt tHwA 1, xAsyt 1, njwjw 1, jnnk 1, dSrw nw sXt 1,

21 „Ha megvizsgálsz egy embert $r A$-jb-je elzáródásával, aki megterhelt a kenyér fogyasztásától” - jr xAj=k s Hr Sna n rA-jb=f, $\mathrm{dns}=\mathrm{f} \mathrm{r}$ wnm t ...

${ }^{22}$ „Ha megvizsgálsz egy embert, aki a rA-jb-jétöl szenved, és úgy találod, hogy átkelt (ti. a mn-szenvedés) a csatornán, és mindkét oldalától szenved, hasa szük a kenyérnek, jb-szíve meg van terhelve ..." (jr xAj=k s Hr mn rA$\mathrm{jb}=\mathrm{f}, \mathrm{jr} \mathrm{gm}=\mathrm{k}$ sw DAj.n=f mr, jw=f mn=f Swtj.fj, jw Xt=f Hns r t, $\mathrm{jw} \mathrm{jb}=\mathrm{f}$ dns=f.

23 „rA-jb szenvedésének az esettanulmányai” - SsAw n mn rA-jb

24 ö a mell(kas)t, pontosabban a thoraxot, esetleg a felsőtest keretét javasolja: Walker 1996, 127-146. A rA-jb anatómiai listában csak a Vatikáni mágikus papiruszon (IV, 3-7: Suys 1934) jelenik meg, a Drww („törzs oldala”) és a HAtj-szív között, majd a máj, a lép, a tüdő és a belek következnek. Ez arra utal, hogy a mellkas része, mely az említett belső szervektől elkülönül Az Ebers papiruszon a mell (Snbt - Eb183-187) és a HAty-szív (Eb219-220) esetei között nevezik meg a betegségeit, ami arra utal, hogy a törzs felső részében helyezkedik el.

A 22. dinasztia idején az jb szívnek - ami ekkor már egyértelműen nem az anatómiai szerv, hanem az ember lelki megfelelője a rA-jb a kápolnája lett (pl. Nb-nTrw önéletrajza / Jansen-Winkeln 2001, I. 122), vagyis egy megszentelt fizikai tér a testen belül. Vö. Allam 1975, 145. (Walker 1996, 133: a Széth feletti győzelem 30. dinasztia és Ptolemaiosz kori változatainak szövege (Urk. VI, 81, 3-10) alapján felveti, hogy a rA-jb nemcsak a HAtj-szív környezetét, vagyis a mellkast jelentette, de előfordulhatott, hogy magát a HAtj-szívet jelölte.) Kérdés azonban, hogy a kápolna értelem, mikor jött létre, ill. vált általánosan elfogadottá. A templom és szív kapcsolata később, az antik világban is jelen volt, ld. Lozsádi K - Király László, Szívparafrázisok. Müvészet, mítosz és filozófia a szívről. Budapest, Medicina, 2013 és Lozsádi - Király 2014, és a középkorban is tovább élt, ld. Király 2013.

http://www.kaleidoscopehistory.hu Győry Hedvig PhD 
psj $\mathrm{Hr}$ mrHt, swj jn s,

rdj.xr=k Drt=k Hr=f, qaH.tj r nDm gAb, Sw m jh,

Dd.xr=k: jw Ah pn hAy r qAb mAa r pHwyt. N wHm sp rswy')

A helyzet súlyosságát jelzi a halálos veszély fenyegetése. A betegséget angina pectoris-nak / koszorúér ischémiának szokták értelmezni.

Magától értetődik, hogy a rA-jb / „szív-szája” könyvében többször is előfordulnak az ib-szívre vonatkozó tünetek: Eb 188: ,jb-szíve gyenge a járáshoz (nem birja), mint egy olyan embernek, aki a fenék tAwlázától/gyulladásától szenved”' ( $\mathrm{jb}=\mathrm{fXsj}=\mathrm{f} \mathrm{r} \mathrm{Sm.(w)t} \mathrm{mj} \mathrm{s} \mathrm{Hr} \mathrm{mn} \mathrm{tAw} \mathrm{nw} \mathrm{pH}[\mathrm{wy}] \mathrm{t}), \mathrm{Eb}$ 196: ,jb-szíve fáradt, mint azé, aki kifulladt(?) a futástól/vándorlástól” ( $\mathrm{jw} \mathrm{jb}=\mathrm{f} \mathrm{bAg}=\mathrm{f} \mathrm{mj} \mathrm{kHw} \times \mathrm{xp}), \mathrm{Eb} 197$ : „ib-szive egyenetlensége" ( $\mathrm{nHAt} \mathrm{jb}=\mathrm{f})$, Eb 198: ,jb-szíve szük" ( $\mathrm{jw} \mathrm{jb}=\mathrm{fHws}=\mathrm{f}), \mathrm{Eb} 205:$, jb-szíve meg van terhelve" (jw $\mathrm{jb}=\mathrm{f}$ dns=f), vagy a már említett Eb 206: ,jb-szíve csapkod" vsz. a palpitáció (jw jb=f aaw=f) - ugyanez a jelenség az Eb 207-ben egy másik tünet együttes része: ,jb-szíve csapkod, arca sápadt, jb-szíve ütemesen(?) ver ... jb-szive forró, Xt-je (test, törzs, has) felpuffadt ..." ( $\mathrm{jw} \mathrm{jb}=\mathrm{f}$ aaw $=\mathrm{f}$, jw $\mathrm{Hr}=\mathrm{f} \mathrm{aAD,} \mathrm{jw} \mathrm{jb=f}$ $\mathrm{jrj}=\mathrm{f} \mathrm{dbdb} . . . \mathrm{jb}=\mathrm{ftA}, \mathrm{Xt}=\mathrm{f}$ stnjt... ).

Egy következő kezelés a Berlini orvosi papiruszon (Bln 151) a vér megtörése, amely a „szétterjedt” $(\mathrm{sSw}) \mathrm{jb}$-szívhez jutott. Ez feltehetően az összeállt vér, a vérrögképződés jelenségét kezeli, ami talán a trombózisnak felel meg, bár a szétterjedés ebben a kontextusban nem igazán értelmezhető (Eb855g: „Azt jelenti, hogy a sziv metuiban széklet van"). Sajnos további tünetet nem neveznek meg. Forróságot is észleltek az jb-szíven (Bln185) - ilyenkor kellemessé kívánták tenni a beteg állapotát. Elképzelhető, hogy égető érzést írtak ezzel körül, és talán lázcsillapításról van szó. Vörös olajat készítettek, és ezt a beteg 4 napig itta. Megfigyeléseik alapján a skorpiócsípés $(B \ln 77)$ esetén szintén szükségesnek látták az jb-szív kezelését. (Ez annál is inkább jogos, mivel a skorpióméreg bénítja a szívizmokat.)

Kérdéses, mit értettek az jb-szív betegségén (mrt jb / Eb217-Eb218). Ennek semmilyen tünetét, vagy panaszt vele kapcsolatban nem jegyeztek le. Egyetlen támpont, hogy ez a baj a mrt szóval van megjelölve, tehát fájdalmas, nem egyszerüen szenvedést okoz, mint a mnt-betegség. Közvetlen a rA-jb esetei után, és a HAtj esetei előtt jegyezték le.

\section{HAtj vagy szív-érrendszer}

Számunkra nem igazán megfogható az a viszonylag gyakorinak tünő betegség, ahol a feladatot az aAa nevü betegség megszüntetése képezi a HAtj-szívben (Eb221-Eb229, Eb236-241, H79-H84) és a törzs más szerveiben. Van olyan feltételezés, hogy ez a horogféreg okozta ankylostomiasisnak felel meg, tehát egy parazita okozta megbetegedés, az egyiptomiak azonban a láthatatlan okozót az istenek között keresték, vagy az isteni szférába került halottaknak tulajdonították. Ha a parazita fertőzés feltételezése bebizonyosodik, akkor ez a súlyos vérszegénységen és fehérjehiányon túli szívelégtelenségre utal.

A tünetekkel kapcsolatba hozhatók a Bln58 receptben leírt óegyiptomi kezelési célkitüzések, ahogy ök fogalmaztak, ,az jb-szív menekvésének, a HAtj-szív [szúrásának], és az jb-szív feledékenységének a legyőzése. A korabeli értelmezésnek megfelelően a szív szúrása azt jelenti, hogy: „HAtj szivére TAw-höség esett, ezért az jb-szíve forró a hőség miatt, mint egy olyan embernél, akit a szúnyog megcsípett." (Eb855s), míg feledékenységét úgy magyarázzák, hogy „A felolvasópap tevékenysége idézi elö, behatol a tüdejébe bajok formájában, és úgy jön ki, hogy az jb-szív figyelmetlen lett." (Eb855u)

Bizonytalanságban hagytak minket, amikor a HAtj-szív pusztán kezeléséről (Eb220, Eb230) beszélnek - ennek is kellett legyen oka, de nem maradt fenn magyarázata. Valószínüleg hőhullámokra utal a „höségköteg” (Eb219) megnevezés a HAtj-szíven. Persze ez is lehetett egyszerűen forró (Eb235). A 
Kaleidoscope

Chester Beatty papirusz egyik receptje (Bt18) alapján az akhet-évszakra, vagyis a nyárra volt jellemzö, így felmerül a hőguta / hőhullám lehetősége, de ha valóban a szívröl van szó, akkor valószínübb a hőség okozta szívelégtelenség (kardinális dekompenzáció).

Máskor a HAtj-szíven jelentkező ukhedu (wxdw)-fájdalomról hallunk (Eb233-234), adott esetben más jelenségekkel együtt (Eb231), mint egy szindróma: „egy halott megszüntetésére a hasban (Xt), egy isten vagy egy halott aAa-jának, az wxdw-fájdalomnak, és mindenféle gonosz dolog ütésének / sebének a megszüntetése" (dr mwt m Xt, dr aAa n nTr, n mwt, wxdw, sqrxt nbt Dwt).

A két szívforma (jb-szív és HAtj-szív-érrendszer) közös bajai

Egyfajta lázas állapotot írnak le az jb-szíven észlelt jelenségekkel a Bln154 receptben, mely olyan kifejezéseket használ, amilyeneket a mintegy évszázaddal korábbi Ebers papirusz 1. traktátusának magyarázatai (Eb855) között értelmeznek: jb-szíve forró és szúr, a beteg a ruhát alig viseli, mivel nehéznek érzi, olyan, mint egy átmulatott éjszaka után szokott lenni az ember. Ehhez a HAtj-szívvel kapcsolatos tünetek járulnak: ez felhős, és mintha az ízét érezné a beteg (ezt az állapotot az éretlen szikomórfüge fogyasztása utáni helyzethez hasonlítják), és mindezt általános fáradtság és székelési gondok kísérik. Bár a tünetegyüttesben nem szerepel, végén az ukhedu (wxdw)-fájdalom széttörésével gyógyították.

\section{Keringési rendszerek}

Mindezek a jelenségek egy rendszer részét alkották, amit a 18. dinasztia elején I. Amenhotep fáraó, majd a 19. dinasztia folyamán II. Ramszesz fáraó uralkodása alatt készült papiruszok meg is őriztek számunkra. Címük alapján a HAtj-szív müködéséről szólnak, két különböző szempont szerint.

Az ún. első anatómiai traktátus az anatómia, az élettan (és néha a kóroktan) keveredése. Két egységre osztották az Ebers papiruszon, egyikben a föszöveg található néhol magyarázatokkal (Eb854), másik csak a szív különböző állapotaira vonatkozó magyarázatokat tartalmazza (Eb855). Kiderül a papiruszból, hogy a HAtj-szív csövei / metui az emberi test minden részébe eljutnak, és beszédüket (a pulzust) valamennyi gyógyításhoz kapcsolódó foglalkozást űző személy megméri a diagnózis felállítása érdekében. A metukban elképzelésük szerint levegő keringett, de említenek más anyagokat is, ${ }^{25}$ hiszen ez a megnevezés nemcsak a mai értelemben vett erekre vonatkozott. Minthogy a halottakban az artériák üresek, logikusnak tünik, hogy ezeket levegővel telítettnek gondolták. (A vénákban viszont halál után is megmarad a vér.) Megfigyelték, hogy a levegö az orron át jutott az emberi szervezetbe, és úgy tudták, hogy onnan egyrészt a HAtj-szív rendszerében haladt tovább, másrészt a tüdőhöz, majd ezekből a szervekből a test további részeihez jutott, köztük az jb-szívhez, amit tehát ebben a szövegben az orvosi értelemben a HAtj-szív egyik egységének tartottak.

A traktátus második fele (Eb855) a magyarázatokat veszi sorra, 26 jelenséget az jb-szívhez, 18 jelenséget a HAtj-szívhez kötve ${ }^{26}$ :

b: baHj jb / elárasztott

c: Ss jb / betegen fekszik (?)

d: XAs(f) - HAtj / kidudorodik

d: Ad xpr m HAtj / a szívben keletkezö bágyadtság

e: amd jb / bágyadt, gyenge, felhös

\footnotetext{
${ }^{25}$ Ritner 2006, 100 véleménye szerint az alapvető folyadék a vér volt, de ez annyira nyilvánvaló lehetett számukra, hogy nem vesztegettek időt az említésére.

26 vö. Westendorf 1999, 112-113.
}

http://www.kaleidoscopehistory.hu Győry Hedvig PhD 
e: tm mDt - HAtj / nem beszél

$\mathrm{f}: \mathrm{ft} \mathrm{jb} /$ bosszús

f: wgg - HAtj / gyenge, öregesen fáradt

$\mathrm{g}: \mathrm{zS} \mathrm{jb} /$ kitárul

h: nDHDH - HAtj / lesüllyed, -lóg (?)

$\mathrm{i}: \mathrm{nDHDH} \mathrm{jb} /$ lesüllyed, -lóg (?)

$\mathrm{i}$ : HT(A) jb / besüllyed

i: $\mathrm{H}(\mathrm{A}) \mathrm{H}(\mathrm{A}) \mathrm{jb} /$ elárasztott

i: HH jb m HAtj / az jb elárasztva a HAtj-ban (Westendorf: ... HAtj minöségében)

k: gwA jb / összesodorva, -kötve

$\mathrm{k}$ : wrd jb / fáradt vö. x. (gyakori Ozirisz jelzőjeként is, amikor látszólagos halálára utalnak, amiböl Ízisz istennő újjáélesztette)

k: mAs jb / térdel, vö. 1 bis - Hety intelmeiben olvasható, hogy mSty=fy $\mathrm{r}$ rA n jb=f, nn tpr.n=f Taw (,térdei az jb-szívének a bejárata felé [ti. nyomódnak], és nem tud levegöt venni”, Helck, DwA-xtjj, 85). Nem tartom kizártnak, hogy egy ilyen térdét hasára húzó testhelyzetre utal a kifejezés, és a nehézlégzés ezen formáját írja körül

$\mathrm{k}: \mathrm{tA}$ - HAtj / forró

$\mathrm{k}$ : HAtj $\mathrm{m}$ st.f $\mathrm{m}$ snfw nw smA / a helyén van, a tüdö vérével együtt vö. $\mathrm{p}$

1: wSr jb / száraz

1: dmA snf m HAtj / „egyesül a vér a HAtj szív-érrendszerben” / vsz. összecsomósodott a vér a szívben, alvadt $=$ halál utáni állapot

1 bis: mAs jb / térdét felhúzva ül, vö. $\mathrm{k}$.

1 bis: ktt / kicsi

1 bis és m: xr wxdw Hr HAtj / az wxdw a HAtj-ra esett

n: rwj HAtj / táncol

$\mathrm{o}$ : hrp jb / besüllyedt

o: dHr jb / keserü, savanyú

p: HAtj m st.f m snfw nw smA / a helyén van, a tüdö vérével együtt vö. $\mathrm{k}$.

q: npA -HAtj / csapkod, üt

$\mathrm{q}: \mathrm{hAj}$ - HAtj / leszáll, lemegy

s: $x n w S$ jb / szúr

s: tAw xns Hr HAtj / höség vonult a szivre

t: jpg jb / felhös

$\mathrm{t}$ : Hbs jb / betakart, beburkolt

u: Aq jb / (el)fogy

$\mathrm{u}$ : thj $\mathrm{jb} /$ figyelmetlen

$\mathrm{u}: \mathrm{mhj} \mathrm{jb} /$ feledékeny vö. $\mathrm{z}$.

$\mathrm{x}$ : wrd jb / fáradt vö. $\mathrm{k}$.

y: nbA jb / örjöng

$\mathrm{v}: \mathrm{mH} \mathrm{m}$ snf - HAtj / vérrel telitett

v: xr swS Hr HAtj / (höség)köteg esett a szívre

$\mathrm{w}$ : wx(A) jb / elsötétült, átmulatott / éjszakás

w: gAw jb / beszükült, lassú, nélkülöz, hiányt szenved

http://www.kaleidoscopehistory.hu

Győry Hedvig PhD 
z: mhj jb / feledékeny vö. u.

$\mathrm{z:} \mathrm{mHj} \mathrm{jb} /$ elárasztva

A metuk különbözö betegségeit sokféle okra visszavezették, melyek többségét külső hatás eredményének tartották. ${ }^{27}$. Ezek szerint betegséget okoznak úgy, hogy közben az érrendszer is megbetegedhet a

- $\quad$ mérgek (víz, széklet, rovarszúrás, wxdw), láz,

- betegséget előidéző lények, ill. az ő hatásuk (halott, dHr.t, nsy/t, felolvasó pap, ,tiszta-pap”) = vsz. pszichoszomatikus betegségek

- a helyes anyagok rossz állapota (összecsomósodott vér) okozza a szervezet betegségeit pl. trombózis, embólia

- $\quad$ a szervek fizikai állapotában bekövetkezett változások, rendellenes mozgásuk vagy elmozdulásuk a helyükről

- $\quad$ metuk elváltozása

2. traktátus

Számon tartották azonban a kór degeneratív eredetének a lehetőségét, az általános leépülés jelenségét is: „Ami azt illeti, hogy "gyengeség a kora (wjAwjt) miatt" - azwxdw-fájdalmat jelent HAtjszivén" (855m (101,11)). A továbbiakban ennek az ukhedu-nak (wxdw) az eseteit vizsgáljuk, melyek a fennmaradt két könyv szerint szoros kapcsolatban állnak a szív-érrendszeri megbetegedésekkel és elváltozásokkal. Bár mindkét mü forrása azonos eredetre utal, a thébai Ebers (§856) papirusz rövidebb változat, míg a Szakkarában talált Berlini papirusz (Brl163) bővebb. Címe alapján mindkét könyv az $\mathrm{wxdw}^{28}$ mozgásáról szól, és végső céljuk „a lepecsételt lábszárak feloldása”. A szövegek törzsét a metu hálózat leírása alkotja, bár az előbb tárgyalt traktátustól eltérő rendszert tárva elénk, hiszen itt csak a fejhez 22 metu vezet.

A fájdalmat okozó wxdw ugyanis a metukban közlekedik. Régebben éppen ezért szívesen fordították az wxdw-t ,mozgó fájdalomnak”. Ma már inkább patogén anyagként említik, vagy fordítatlanul hagyják, mivel a mozgást a szövegek nem a fájdalom helyének a változására értik, hanem, hogy a páciensek ugyanazt a fájdalmas jelenséget különbözö helyeken érzékelik. Az wxdw jelenlétének kiemelését a mell, comb, felkar és fenék / végbél esetében tartották fontosnak. Megállapításuk szerint az wxdw előre haladta életveszélyes volt, hiszen a végső szakasz a láb elhalásával kezdődik, és fokozatos terjedése az ember halálát okozza. A „2. traktátusban” ennek a folyamatnak az elemeit írták bele.

\footnotetext{
${ }^{27}$ Részletes tárgyalását ld. Győry, 2002.

${ }^{28}$ Steuer 1948 feltételezi, hogy az egyiptomiak a mumifikáláskor megfigyelték, hogy elöször a belek kezdenek bomlani, majd a bomlás ezután terjed át a többi testrészre, és ebben a folyamatban a végbél kulcsszerepet játszik, ugyanis innen jut el a bomlás, tehát a bomlást előidéző anyag is a HAtj-ba, - ezért lett tehát a mtw hálózat egyik végpontja a végbél, és központja a HAtj-szív. Ez a szenvedést, leépülést okozó anyag az wxdw, melynek meghatározó jele, a kifakadt fekély rajza így válna érthetővé. Ezek szerint a knidoszi görög orvosi iskola perittomajához hasonlóan müködne.

Th. Bardinet szerint az wxdw az erekben okozott TAw lázat, általános gyengeséget, gennyesedést és kiválasztási rendellenességeket, de természetes helyén, a tápcsatornában éppen hogy pozitív hatást fejtett ki (Bardinet 1995, 132-133.). Westendorf 1999, 329-343: „fájdalomanyagnak” fordítja, és olyan anyagnak tartja, ami betegséget okoz. Fontosnak tartja, hogy az egyiptomiak az wHAw-kiütés gyökerének tekintették (Eb103). Központi helyét a has/gyomor tájékára teszi, ahonnan a meturendszeren keresztül gyakorlatilag mindenüvé eljut.
}

http://www.kaleidoscopehistory.hu Győry Hedvig PhD 
Kaleidoscope

A levegő szervezetbe jutásával kezdik, aminek látszólag semmi köze sincs a továbbiakhoz, hiszen az wxdw-t itt nem említik. Közvetlen ez után a mell két metu-ja következik, mégpedig a fenék / végbél lázával hozva összefüggésbe, amit itt a keringési rendszerük végpontjának tekintettek. $\mathrm{Az} w x d w$ szempontjából a másik kiemelt jelentőségü hely a comb volt, amit a karral hoztak kapcsolatba - ha beteg a láb, akkor a kar is gyenge. A következő megállapítás, hogy a felkar betegsége az ujjban váladékképződést okoz. Ugyan ezt követően felsorolnak több metut, de nem említenek velük kapcsolatban semmit sem a fül kivételével, amin keresztül az élet és a halál lehelete áthalad. Ahogy a páciensben tovább haladnak az wxdw anyagok, „Miután egészen a HAt j-szivéig mentek, és szétoszlottak (psS. tw) az orra felé, a végbélnél egyesülnek. Bennük keletkezik a végbél betegsége. A váladékok (wsSw) azok, amik járását vezetik (Ssm). A két láb metui azok, amelyek elkezdenek meghalni." (Bin 163h (16,316,5) vö. Eb 856h)

Rendszerükben tehát az élet leheletének távozását, a HAtj müködésének leállását elöször a láb bénulása jelzi (Eb 856h). ${ }^{29} \mathrm{Ez}$ azt jelenti, hogy az wxdw a metu-hálózat egy halálos kimenetellel fenyegető betegségének állandó kísérője, okozója volt, mely fokozatosan haladt előre a maga útján. Nem csoda, hogy a traktátus bevezetőjében külön kiemelték a kezelő szunu-orvos kiválóságát, és az istenekkel kialakítandó jó kapcsolatát. Felismerésük szerint tehát a láb mozgásképtelensége és fájó volta összefüggött, és az ember halálát elöre jelezte. A fentiek alapján ez ugyan nagyon egyszerüsített, de jogos megállapítás, mivel a szöveg egy súlyos érelmeszesedés leírása a láb gangrénájával és ennek fokozatos terjedésének a következményeként fellépő szepszissel. Az elsőként említett comb gyengesége és a kar erejének elvesztése közötti összefüggés arra mutat, hogy megfigyelték, hogy ha - mai kifejezéssel - a szívelégtelenség miatt fájdalmas végtagduzzanat (oedema) alakul ki a páciensen, akkor a szívizom gyenge, és az ember fáradékony. Ennek egyenes következménye, hogy a szív gyenge müködése miatt gyenge a karja is. Ha érelzáródás miatt elhal a comb ere, akkor a szepszis miatt megint általános gyengeség alakul ki. A felkar és az ujj esetében valójában fordított a helyzet, de ezt úgy tünik, nem tudták elkülöníteni - valószínüleg arról van szó, hogy a gennyesedés (panaritium) vagy más ujj-sérülés miatt gyulladás (phlegmone) alakul ki. A végső stádiumban a láb elhalása trombózis és gangrénaként értelmezhető, hiszen a metu betegsége miatt alakult ki a mozgásképtelenség. Ez egyértelmü a szövegkörnyezet és a konkrét fogalmazás alapján egyaránt: „A két láb metui azok, amelyek elkezdenek meghalni." (Bln 163h és Eb856h). A jelenséget tehát a korszakban ismert keringési rendszerrel magyarázták. Mint a fennmaradt szövegek mutatják, úgy látták, hogy éppúgy előidézhették külső körülmények, mint az öregedés folyamata. Vagyis ez a leírás egy súlyos érelmeszesedés leírása a láb üszkösödésével és ennek fokozatos terjedésének a következményeként fellépő vérmérgezéssel.

\section{Múmiavizsgálatok}

De vajon az erek megbetegedése mennyire volt jellemző az ókori egyiptomiak világára? Erre a múmiák vizsgálata adhat választ. Ennek során ugyanis már 1852. október 7--én Joseph Czermak „nagy és meszes plakk lerakódások" észleléséről számolt be egy idősebb óegyiptomi nő múmiájának az aortáján

\footnotetext{
${ }^{29}$ vö. Ritner 2006, 100-101 magyarázata szerint az élőkön és halottakon tapasztaltak összegződnek itt a történelem első természetes betegség teóriájában. A folyamat azért kezdődik a lábbal, mivel ez van a legközelebb a belekhez és végbélhez, amik a patogén anyagok székhelyei. A Hérodotosznál említett olcsó mumifikálási eljárás (II.87-88) is ezért a végbélen keresztül távolítja el a belső szerveket. Megfigyelésen alapuló bonyolult rendszert alakítottak ki. Tekintve, hogy az wxdw a test bármely részén megjelenhet a sebekben, egyértelmü, hogy felismertek egy bizonyos körforgást, pl. levegö belépése az orron át, onnan a szívbe és tüdőbe, majd ,az egész testbe”.
}

http://www.kaleidoscopehistory.hu Győry Hedvig PhD 
Kaleidoscope

végzett mikroszkópos vizsgálat eredményeként, ${ }^{30}$ majd Marc Armand Ruffer tett hasonló felfedezést több, közvetlen az Asszuáni gát 1907-es építése előtt feltárt ókori egyiptomi múmián és végtagon, amit 1908 végén a Kairói Tudós Társaság ülésén jelentett be. Ő kialakított egy olyan módszert, amivel rehidratálhatóvá váltak a múmiák, és így a mikroszkóp alatt már jól vizsgálhatók lettek a szövetek. A boncolások során azt tapasztalta, hogy különösen a nagy artériák teljesen kilaposodtak, mintha kivasalták volna öket, viszont jól láthatóak voltak a meszes vagy fibroid elváltázások, a lumen pedig sokszor szűk volt. A leginkább feltünő változást a kismedencei és alsóvégtagi artériáknál észlelte. ${ }^{31}$ Vizsgálata eredményeként kiderült, hogy az erek meszesedése általánosan elterjedt volt ezen a területen a belső és középső falon egyaránt, sőt sokszor még az izmokon is jól érzékelhető elváltozást okozott. Eredményeit és következtetéseit nem sokkal később cikkében, majd könyvében is megírta. ${ }^{32}$ Véleménye szerint a betegség anatómiai jellege azóta sem változott, és épp annyian szenvedtek érelmeszesedésben az ókorban, mint saját korában. Két évtizeddel később ismét megjelent egy cikk, ezúttal a 21. dinasztia korában élt Teje szívkoszorúerének meszesedéröl (CAD) Allan R. Long tollából, ${ }^{33}$ majd hosszú hallgatás következett e téren.

A 2000-es években, az orvostudományban előtérbe kerültek az érelmeszesedéssel kapcsolatos kutatások, és szinte berobbant a köztudatba a Hórusz Study kairói CT vizsgálati eredménye $\left(2009,{ }^{34} 2010^{35}\right)$, mely az egyiptomi múmiákon nagy mennyiségben mutatta ki az atherosklerózis különféle formáit. ${ }^{36} \mathrm{~A}$ nemzetközi kutatócsoport a továbbiakban $\left(2013^{37}\right)$ perui indián és észak amerikai pueblo indián valamint unangan eszkimó múmiák CT vizsgálatát végezte el, így összesen 137 (77 férfi, 44 nő, és 16 azonosítatlan nemü) múmiát vizsgáltak, 36 éves átlagéletkorral, 5 területre összpontosítva: 1, nyaki ütőér, 2, koszorúér, 3, föütöér, 4, csípö-combcsonti és 5, térdhajlati/sípcsonti ér. A biztosan vagy valószínüsíthetően atherosklerózisos múmiák átlagéletkora 42-44 év volt, az elváltozásnak korral növekvő kiterjedésével, és a nőknél valamivel nagyobb arányban. Megállapítást nyert tehát, hogy az életkor jelentősen befolyásolja a kór kialakulását, és noha a modern orvostudomány által meghatározott tényezők (helytelen étkezés, mozgáshiány, dohányzás, stressz) ${ }^{38}$ és a cukorbetegség ${ }^{39}$ fontosak, további tényezőket is számításba kell venni a betegség kialakulása és kifejlődése kapcsán ${ }^{40}$.

Tekintve, hogy ezek az emberek különböző életmódot folytattak, és táplálkozásuk is eltért egymástól, de a maitól is, a betegség kialakulását előidéző új rizikófaktorok után kezdtek kutatni. A múmiák alapján úgy tünik, hogy a szervezetben fennálló idült gyulladás/fertőzés és a tüdő betegségei (tuberkulózis,

\footnotetext{
${ }^{30}$ Czermak 1852, 462-463: a 2 múmiát a Böhmishes Museum adta át a szintén prágai Physiologische Intitut-nak, egyik (c. 15 éves körülmetélt fiú, M:1,35 m) hiányos és rossz állapotú volt, a másik (felnőtt nő, M:1,53 m) viszont szinte teljesen ép. Czermak rendkívül sok pólya eltávolítása után vizsgálta meg őket, és számos mintát vett mikroszkópos vizsgálat számára is.

${ }^{31}$ Ruffer 1921, p. 22-23.

${ }^{32}$ Ruffer 1911; Ruffer 1921, 20-31.

${ }^{33}$ Long 1931. 92-94.

${ }^{34}$ Allam et alii 2011, Allam et alii, 2009, 2091-2093.

35 Allam et alii 2010.

36 A meszesedés lehetséges okainak megvitatása: Charlier - Huynh, 2010, Thomas, 2010.

37 Thompson 2013, BMJ 2013.

38 Érvényesülésük a táplálkozással kapcsolatban a múmiákon is jól érzékelhető, pl. David 2010a, David 2010b.

39 Vö. modern orvosi megfigyelés: Lehto et alii 1996.

40 Mint Ötzi múmiája mutatja, az öröklött hajlam sem mellékes, és a teljes DNS-ekben levő SNP segítségével ez is vizsgálható, amit az egyiptomi múmiák esetében is vizsgálni szeretnének. Zink et alii, 2014.
}

http://www.kaleidoscopehistory.hu Győry Hedvig PhD 
Kaleidoscope

anthrakózis) szintén fontos rizikófaktorok. ${ }^{41} \mathrm{Az}$ eredmények elemzése egyértelművé tette, hogy az atherosklerózis kialakulási okainak a feltárásához további kutatások szükségesek.

Áttekintve azokat az eseteket, melyeknél a kutatók érelmeszesedést tapasztaltak, megállapítható, hogy nem ritka közöttük az alsóvégtagi meszesedés, melynél ma is sok a szövődmény és nagy az amputációs rizikó $^{42}$, különösen a cukorbetegek ${ }^{43}$ és vesebetegek ${ }^{44}$ körében. A lábszárra vonatkozó meszesedésekre példaként említhető II. Ramszesz múmiája, ${ }^{45}$ vagy a kairói vizsgálatok során a csípő-combcsonti és térdhajlati/sípcsonti érben talált meszesedések: a 2009-ben vizsgált 16 múmiából 9-nél találták meg az érelmeszesedés nyomát, ami ebböl 7 esetben a végtagokat érintette, ${ }^{46}$ míg 2011-ben 52 múmia között 20nál, és ezek közül 15 esett a fenti csoportokba. ${ }^{47}$ Prágában 3 múmiát vizsgáltak meg, és egyiküknél a perifériás kiserek mediális rétegében állapítottak meg meszesedést. ${ }^{48}$ És bár jellemzően csak múmiákon kutatják a meszesedést, hiszen a szövetek ott őrződnek meg, érdekes módon a mell és has tájékon kívül, a combcsont mellett is találtak a núbiai Amara temetőinek a feltárásakor szabad szemmel is kivehető plakk képződmény maradványokat csontvázas temetkezésben. ${ }^{49}$

\section{Összegzés és kitekintés}

A Horus-Study során kimutatott atherosklerózis nagyszámú jelenléte a különböző, modern kort megelőzö, hagyományos életmódot folytató népek, köztük az ókori egyiptomiak körében, már magában is meglepő volt, mivel a közismert rizikófaktorok nem, vagy legalábbis modern formájukban nem voltak akkor jelen. A kutatások során azonban részben ezek korábbi változatait azonosították, részben új szempontok is felmerültek. Figyelemre méltó, hogy az érelmeszesedésben szenvedők között jelentős mértékben kimutatható a végtagok meszesedése.

Az egyiptomiak orvostudományát nem véletlenül tartották olyan fejlettnek, hogy a görög tudósok fontosnak tartották akár személyes találkozásokon keresztül is megismerni. Egyiptomban a keringési, ahogy ők hívták a metu-rendszer állapotát, alapvető ismeretként kezelték - a pulzus mérésével következtettek rá. A 2. anatómiai traktátus ugyanakkor nem egyszerüen a vérkeringés korabeli modelljét írja le, hanem annak a felismerésnek is hangot ad, hogy bizonyos betegségeket, itt nevezetesen az alsó végtagok mozgásképtelenségét létre hozhatta a keringési rendszerbe került, és azon keresztül fájdalmat okozó patogén anyag, amit ukhedunak (wxdw) neveztek. Ez pedig váladék formájában volt érzékelhető. Ha meggondoljuk, hogy a megkeményedett végtagduzzanatot (indurált ödémát), amit az óegyiptomiak a „lepecsételt láb” szókapcsolattal fejeztek ki, fekélyesedés követte, egyértelmü, hogy kívülről is jól láthatóvá válhatott a gennyes folyadék. Nyilvánvaló volt tehát számukra a metuk megbetegedése által elhalt láb és az azt követö elhalálozás közti összefüggés, vagyis a végtagok keringésének leállása által kialakult betegség, majd halál.

${ }^{41}$ Clarke et al. 2014; Thomas et alii, 2014a.

42 Guzman et alii 2008.

${ }^{43}$ Levin - O'Neal 2008, Aulivola - Pomposelli 2012. Nagy valószínüséggel ilyen eset nyomát őrizte meg

Tabaketenmut múmiája Thébában (TT-95), ahol a jobb nagylábujj levált, és protézissel helyettesítették. (Nerlich et alii 2000, Finch 2011.)

${ }^{44}$ McCullough et alii 2008

45 Whitehouse 1980.

46 Allam et alii 2009, 292, a táblázatban a 9, 11, 12, 13, 14, 15, 16 számú múmiák.

47 Allam et alii 2011, 318-319.

48 Vyhnanek - Strouhal 1975.

49 Binder - Roberts 2014.

http://www.kaleidoscopehistory.hu Győry Hedvig PhD 
Kaleidoscope

Ez annál is érdekesebb, hiszen a lábbénulás, -fekélyesedés és a vérkeringés közötti összefüggés az európai orvostudomány számára csak a 19. században, Jean Cruveilhier (1791-1874) munkássága nyomán vált ismertté. ${ }^{50} \mathrm{Az}$ ókori egyiptomiak megfigyelése tehát ebből a szempontból teljes mértékben egybevág a modern orvostudomány ismereteivel, amennyiben az érelmeszesedés leggyakrabban a perifériális erekben, leginkább a láb ereinek a meszesedésében nyilvánul meg - és ez hazánkban is igen gyakori jelenség ${ }^{51}$. Ha pedig az ilyen betegek csak a végső szakaszban jutnak orvosi kezeléshez, akkor gyakran csak amputálással tudják életben tartani őket - ami az ókorban lényegesen veszélyesebb beavatkozásnak számított. Magyarországon ma a halálokok több mint harmada keringési betegségre vezethető vissza, ${ }^{52}$ és a lakosság $\mathrm{kb}$. tizede szenved végtagmeszesedésben. Szerencsére a tudomány fejlődésével, és a megelőzés előtérbe kerülésével egyre kevesebb embernél áll fenn az a helyzet, hogy a vérellátás hiánya miatt lábszárfekély alakul ki, ami az ókorban legtöbb esetben gyógyíthatatlan volt, és kezelését ilyenkor csak a rendkívül veszélyes végtag amputációval lehetett megoldani, amire az ókori Egyiptomból kevés sikeres példát ismerünk, ${ }^{53}$ így a végtagok mozgásképtelenné válása valóban halálos fenyegetettséget jelentett.

Irodalom

Allam et alii 2009 = Allam, A.H. - Thompson, R.C. - Wann, L.S. - Miyamoto, M.L. - Thomas, G.S., Computed tomographic assessment of atherosclerosis in ancient Egyptian mummies, JAMA, 302 (2009), pp. 2091-2093. https://doi.org/10.1001/jama.2009.1641

Allam et alii $2010=$ A. Nureldin, G. Adelmaksoub, Adel H Allam, - Abdelhalium Nureldin - Gomma Adelmaksoub -Ibrahem Badr -4 Hany Abdel Amer - Muhamed Al-Tohamy Soliman - Gregory S Thomas - Randall C Thompson - Michael I Miyamoto - Ian G Thomas - Adam Thompson - Samuel Wann,, Something old, something new-computed tomography studies of the cardiovascular system in ancient Egyptian mummies, Am Heart Hosp J, 20 (2010), pp. 10-13. https://doi.org/10.15420/ahhj.2010.8.1.10 Allam et alii $2011=$ Adel H. Allam et alii, Atherosclerosis in Ancient Egyptian Mummies. The Horus Study, JACC 4/4, 2011, 315-327. https://doi.org/10.1016/j.jcmg.2011.02.002

Allam, S., Papyrus Moscow 127 (Translation and notes), JEA 61/1975, 147-153. https://doi.org/10.1177/030751337506100114

Long 1931 = Allen R. Long, Cardiovascular renal disease: a report of a case three thousand years ago, Arch Pathol (Chic), 12 (1931), pp. 92-94.

Assmann 1993 = Assmann, Jan, Zur Geschichte des Herzens im Alten Ägypten, in Theo Sundermeier (ed.), Die Erfindung des inneren Menschen. Studien zur religiösen Anthropologie, Gütersloh 1993, 81-112.

Assmann 1994 = Assmann. Jan, Individuum und Person. in G.Boehm - E.Rudolph, (eds), Individuum. Probleme der Individualität in Kunst, Philosophie und Wissenschaft. Stuttgart 1994, 185-219.

\footnotetext{
${ }^{50}$ Cruveilhier 1828-1842 művében a phlebitis kapcsán, amit makroszkopikus megfigyelések alapján fedezett fel. Vö. Richardson 1863, Kosif 2019.

${ }^{51}$ Szegedi, János dr, A perifériás érbetegségek rizikófaktorai, Magyar Atherosclerosis Társaság, 2020: http://metabolizmusonline.hu/cikkek/a-periferias-erbetegsegek-rizikofaktorai-metab ...”a diagnosztizált perifériás érbetegségek 5 éves mortalitása eléri a 30\%-ot. Ma Magyarországon az évi végtagamputációk száma meghaladja a 6500-at." ...

${ }^{52}$ https://www.egeszsegkalauz.hu/betegsegek/sziv-es-errendszeri-betegsegek/az-ischaemias-szivbetegseg-okai-eskezelese/t18v22q

${ }^{53}$ ld. Győry-Horváth-Blázovics előadása a „Health and Life in Ancient Egypt” konferencián (2019 aug.) http://www.kaleidoscopehistory.hu Győry Hedvig PhD
} 
Kaleidoscope

Aulivola-Pomposell 2012 = Aulivola, Bernadette - Pomposelli, Frank B. Jr., Lower-limb Arterial Reconstruction in Patients with Diabetes Mellitus: Principles of Treatment. in: A. Veves et al. (eds.), The Diabetic Foot: Medical and Surgical Management, Contemporary Diabetes, Springer Science+Business Media, LLC 2012, 347-368. https://doi.org/10.1007/978-1-61779-791-0_19

Bardinet $1995=$ Th. Bardinet, Les papyrus médicaux de l'Egypte pharaonique, Paris 1995

Binder-Roberts 2014 = Binder M. - Roberts, C.A:, Calcified structures associated with human skeletal remains: possible atherosclerosis affecting the population buried at Amara West, Sudan (1300-800 BC), International Journal of Paleopathology 6/2014, 20-29. https://doi.org/10.1016/j.ijpp.2014.03.003 BMJ $2013=$,Whole mummy” scans confirm ancient atherosclerosis, British Medical Journal 346/2013, 1591. https://doi.org/10.1136/bmj.f1591

Breated 1901 = Breasted, H.J., The Philisophy of a Memphite Priest, ZÄS 39, 1901, 458-479. https://doi.org/10.1524/zaes.1901.39.jg.39

Breasted, J.H. The Edwin Smith Surgical Papyrus, OIP 3-4, Chicago 1930.

Brothwell 1998. - Brothwell, Don Patricia, Food in Antiquity: A Survey of the Diet of Early Peoples. Baltimore: The Johns Hopkins University Press, 1998.

Brunner 1977 = Brunner, Helmut, "Herz"- Lexikon der Ägyptologie II.(1977), cols. 1158-1168.

Brunner 1965 = Brunner. Helmut, "Das Herz im Aegyptischen Glauben" - Das Herz im Umkreis des Glaubens. Biberach an der Riss. 1965;

Charlier - Huynh $2010=$ Charlier, Philip - Huynh, Isabelle, Assessment of Atherosclerosis in Egyptian Mummies, JAMA 303/12, 2010, 1149-1150 https://doi.org/10.1001/jama.2010.326

Clark 2014 = Clarke, Emily M. et al., Is atherosclerosis fundamental to human aging? Lessons from ancient mummies, Journal of Cardiology, 63/5, 2014, pp. 329-334; https://doi.org/10.1016/j.jjcc.2013.12.012

Cruveilhier 1828-42 = Cruveilhier, Jean, Anatomie pathologique du corps humain ou description des diverses altérations morbides dont le corps humain est susceptible avec figures lithographiées et coloriées, $1828-1842$

Czermak 1852 = Czermak, Joseph, Beschreibung und mikroskopische Untersuchung Zweier Agyptischer Mumien, S.B. Akad. Wiss. Wien, 9, 1852. 427-469.

David 2010a = David, Rosalie, Cardiovascular disease and diet in ancient Egypt. In: Hawass Z, Woods A (eds.), Egyptian Culture and Society: Studies in Honor of Naguib Kanawati. Annales du Service des Antiquites de l'Egypte. Vol. 1. Cairo, Egypt: Conseil Supreme des Antiquites de l'Egypte, 2010:105-17.

David 2010b = David, Rosalie, The art of medicine - atherosclerosis and diet in ancient Egypt, Lancet, 175 / 2010, pp. 718-719. https://doi.org/10.1016/S0140-6736(10)60294-2

Ebers 1875 = Ebers, Georg Moritz - Stern, Ludwig, Papyrus Ebers. Das hermetische Buch über die Arzneimittel der alten Aegypter in hieratischer Schrift, mit Inhaltsangabe und Einleitung versehen Mit hieroglyphisch-lateinischem, von W. Engelmann, Leipzig, 1875.

Edwards $1960=$ Edwards, I. E. S., Oracular Amuletic Decrees of the Late New Kingdom (HPBM 4; London, 1960.

Finch 2011 = Finch, Jacqueline, The Art of Medicine. The Ancient Origins of Prosthetic Medicine. The Lancet Vol 377 February 12, 2011, 548-549.) https://doi.org/10.1016/S0140-6736(11)60190-6

Ghalioungui 1987 = Ghalioungui, Paul, The Ebers papyrus. A new English Translation, Commentaries and Glossaries, Cairo 1987. 
Guzman et alii 2008 = Guzman, J.R. - Brinkley, D.M. - Schumacher, P.M. - Donohue, R.M.J. - Beavers, H. - Qin, X., Tibial artery calcification as a marker of amputation risk in patients with peripheral arterial disease, J Am Coll Cardiol, 51 (2008), pp. 1967-1974 https://doi.org/10.1016/j.jacc.2007.12.058

Győry 2002 = Győry, Hedvig, Medicina Theoretica Aegyptiorum, Orvostörténeti Közlemények, 178-181, 2002, 445-73.

Győry 2008a = Győry, Hedvig, Surgery in Ancient Egypt, in: H. Seline (ed.), Encyclopedia of the History of Science, Technology, and Medicine in Non-Western Cultures, Springer DE, 2008, 2053-2059. https://doi.org/10.1007/978-1-4020-4425-0_9795

Győry 2008b = Győry, Hedvig, Medicine in Ancient Egypt. in: H. Seline (ed.), Encyclopedia of the History of Science, Technology, and Medicine in Non-Western Cultures, Springer DE, 2008, 1508-1518.

Helck 1955 = Helck. W., Bemerkungenzu den Bezeichnungen für einige Körperteile, ZÄS 80, 1955, 144145; https://doi.org/10.1007/978-1-4020-4425-0_9748

Hintze 1955 = Hintze, F., Zu den Worten für "Herz” und "Magen” im Ägyptischen. ZÄS 29, 1955, 140142 ,

Jansen-Winkeln 2001 = Jansen-Winkeln, Karl, Biographische und religiöse Inschriften der Spätzeit aus dem Ägyptischen Museum Kairo. In: Ägypten und Altes Testament. (ÄUAT) Nr. 46, Wiesbaden 2001.

Király 2013 = Király, László, The heart in the mosque and the gothic cathedral, Kaleidoscope 2013. Vol.4/7. https://doi.org/10.17107/KH.2013.7.231-245

Klotz 2015 = Klotz, David, The cuboid statue of Ser-Djehuty, Master Sculptor in Karnak. Los Angeles County Museum of Art 48.24.8 + Cambridge University, Museum of Archaeology and Anthropology 51.533. Revue d'Égypte 66, 2015, 51-91.

Kosif $2019=$ Kosif, Rengin, Jean Cruveilhier and His Explorations, World Journal of Research and Review (WJRR) 8/4, April 2019, 29-31. https://doi.org/10.31871/WJRR.8.4.12

Lehto et alii 1996 = Lehto, S. - Niskanen, L.Suhonen et al., Medial artery calcification: A neglected harbinger of cardiovascular complication in non-insulin dependent diabetes mellitus, Arterioscler Thromb Vasc Biol, 16 (1996), pp. 978-983 https://doi.org/10.1161/01.ATV.16.8.978

Levin - O'Neal 2008 = Levin - O'Neal, The Diabetic Foot (Seventh Edition), 2008, pp. 429-442: Chaper 21.

Lozsádi-Király 2014 = Lozsádi K. - Király, László: Még egyszer a szívkatedrálisról. Paradogmák a szív szimbolikájához, Lege Artis Medicinae. 2014, 24/3, 142-150,

McCullough et alii 2008 = McCullough, P.A. - Agrawal, V. - Danielewicz, E. - Abela, G.S., Accelerated atherosclerotic calcification and Monckeberg's sclerosis: a continuum of advanced vascular pathology in chronic kidney disease, Clin J Am Soc Nephrol, 3 (2008), pp. 1585-1598. https://doi.org/10.2215/CJN.01930408

Müller 1966 = Müller, D., "Die Zeugung durch das Herz in Religion und Medizin der Aegypter.", Orientalia 35. (1966), 247-274.

Nerlich et alii $2000=$ Nerlich, Andreas G - Zink, Albert - Szeimies, Ulrike - Hagedorn, Hjalmar G, Ancient Egyptian prosthesis of the big toe, The Lancet Vol 356, December 23/30, 2000, p. 2176-2178 https://doi.org/10.1016/S0140-6736(00)03507-8

Piankoff 1930 = Piankoff, Alexander, Le “coeur”, dans les textes égyptens depuis l'Ancien jusqu' à la fin du Nouvel Empire. Paris, 1930.

Richardson 1863 = Richardson, B.Wills, Phlebitis and Thrombosis. Dublin, Thomas Deey, 1863.

http://www.kaleidoscopehistory.hu Győry Hedvig PhD 
Ritner 2006 = Ritner, Robert K., The Cardiovascular System in Ancient Egyptian Thought, JNES 65/2, 2006, 99-109. https://doi.org/10.1086/504985

Ruffer 1910 = Ruffer, Marc Armand, " Remarks on the Histology and Pathological Anatomy of Egyptian Mummies," Cairo Scientific Journal, Vol. IV, January, 1910.

Ruffer 1911 = Ruffer, Marc Armand, On arterial lesions found in Egyptian Mummies (1580 BC-535 AD), J Pathol Bacteriol, 16 (1911), pp. 453-462. https://doi.org/10.1002/path.1700150403

Ruffer 1921 = Ruffer, Marc Armand, Studies in the Palaeopathology of Egypt. Chicago, The University of Chicago Press, 1921

Schott 1954 = Schott, Siegfired, Die Deutung der Geheimnisse des Rituals für die Abwehr des Bösen. Abhandlungen der Geistes- und Sozialwissenschaftlichen Klasse / Akademie der Wissenschaften und der Literatur in Mainz (=AAWLM) 1954, Nr. 5, Wiesbaden 1954.

Steuer 1948 = Steuer, R. O., wxdw. Aetiological Principle of Pyaemia in Ancient Egyptain Medicine. Supplemenents to the Bulletin of the History of Medicine Nr. 10, Baltimore 1948.

Suys 1934 = Suys. P. E., Le papyrus magique du Vatican, Orientalia 3 (1934), 63-87.

Thomas, Gregory S. et alii $2014=$ Thomas, Gregory S. et alii, Why Did Ancient People have Atherosclerosis. From autopsies to Computed Tomography to Potential Causes, Global Heart 9, 2014, 229 237. https://doi.org/10.1016/j.gheart.2014.04.002

Thomas $2010=$ Thomas, Gregory S., In reply, JAMA 303/12, 2010, 1150. https://doi.org/10.1001/jama.2010.327

Thompson et alii 2013 = Thompson, Randall C - H Allam, Adel - Lombardi, Guido P - Wann, L Samuel Sutherland, M Linda - Sutherland, James D - Soliman, Muhammad Al-Tohamy - Frohlich, Bruno Mininberg, David T - Monge, Janet M - Vallodolid, Clide M - Cox, Samantha L - Abd el-Maksoud, Gomaa - Badr, Ibrahim - Miyamoto, Michael I - Nur el-din, Abd el-Halim - Narula, Jagat - Finch, Caleb E - Thomas, Gregory S., Atherosclerosis across 4000 years of human history: the Horus study of four ancient populations, The Lancet 10 March, 2013, 1-12. https://doi.org/10.1016/S0140-6736(13)60598-X

Vyhnanek-Strouhal 1975 = Vyhnanek, Lubos -Strouhal, Eugen, Arteriosclerosis in Egyptian Mummies, Source: Anthropologie 13/3, 1975, pp. 219-221

Walker 1996 = Walker, James H., Studies in Ancient Egyptian Anatomical Terminology, The Australian Center for Egyptology Studies 4, Warminster 1996.

Westendorf 1999 = Westendorf, W., Handbuch der altägyptischen Medizin 1-2, Leiden-Boston-Köln 1999. Whitehouse 1980 = Whitehouse WM, Radiologic findings in the royal mummies. In Harris JE, Wente EF, eds An X-ray Atlas of the Royal Mummies. Chicago: University of Chicago Press, 1980, 286-328.

Wreszinski 1909 = Wreszinski, Walter, Der grosse Medizinische Payrus des Berliner Museums (Pap. Berl 3038), Leipzig 1909.

Wreszinski 1913 = Wreszinski, Walter, Der Papyrus Ebers, Umschrift, Übersetzung und Kommentar, Leipzig 1913.

Zink et alii $2014=$ Zink, Albert et alii, Genomic Correlates of Atherosclerosis in Ancien Humans, Global Heart 9/2, 2014, 203-209. 